in den Rohren $V$ zu kochen und gerät im Umlaufsystem in Bewegung. Wenn der Spiegel den Punkt $E$ erreicht, wird wiederum Flüssigkeit durch Öffnen des Hahnes $H_{1}$ nachgefüllt. Auf diese Weise können beliebige Volumina abdestilliert werden. Die Leistungsfähigkeit richtet sich nach der Größe der Apparatur, nach der Art der Beheizung und der Wirksamkeit des Kühlers. Wenn die Destillation zu Ende geht und der Flüssigkeitsspiegel den Punkt $E$ erreicht hat, wird die Beheizung abgestellt und weiterhin evakuiert. Durch den Wärmeaustausch an der großen Oberfläche der Rohre $V$ geht die Destillation langsam weiter, wodurch in schonender Weise das Endvolumen noch weiter vermindert wird. Zuletzt wird nach Aufheben des Vakuums das Konzentrat nach Öffnen der Hähne $H_{1}$ und $H_{2}$ abgelassen.

University of California at Los Angeles

\title{
Note on the Polarography of Carbonyl Compounds
}

\author{
By
}

\section{William R. Crowell}

\section{(Received January 2, 195\%)}

In a forthcoming issue of the Journal of the American Chemical Society will appear an article entitled "Polarography of Carbonyl Compounds. III. Semiempirical and Empirical Relationships between Structures and Half-wave Potentials" under the authorship of Dale M. Coulson, William R. Crowell and S. Kathleen Tendick. While this work is a marked departure from the past offerings of one of these authors in Mikrochimica Acta, it is hoped that it may be of some interest to our distinguished colleague, Dr. Hans Lieb, as well as our other Mikrochimica Acta. friends. Therefore we present the following brief summary. In line with work previously reported in two articles in the Journal of the American Chemical Society ${ }^{1}$ (Polarography of Carbonyl Compounds I and II) the present investigation deals with an attempt to show the relationship between the structures and half-wave potentials of ortho, meta and para substituted benzaldehydes and acetophenones in $50 \%$ dioxane solutions. Two series of equations expressing this relationship are derived. The first series is based on the linear combination of atomic orbitals - molecular orbital theory, and the second series involves Hammett's sigma constants: Experimental resilts compare very favorably with those caleulated by these equations as well as those based on the free-electrongas theory.

1 D. M. Coulson and W. R. Crowell, J. Amer. Chem. Soc. 14, 1290, 1294 (1952). 